\title{
"The Executive Branch Shall Construe": The Canon of Constitutional Avoidance and the Presidential Signing Statement
}

\section{INTRODUCTION}

In late April of 2004, 60 Minutes II sparked national outrage when it aired a story revealing photographs of American soldiers subjecting detainees at Iraq's Abu Ghraib prison to appallingly abusive treatment. ${ }^{1}$ This scandal served as at least partial catalyst for Senator John McCain, himself a victim of torture while a prisoner of war in North Vietnam, to propose legislation categorically forbidding future conduct of this sort. ${ }^{2}$ In December of 2005, President George W. Bush signed into law the Detainee Treatment Act of 2005, otherwise known as the McCain Amendment, which prohibits the "cruel, inhuman, or degrading treatment or punishment" of anyone in U.S. custody, regardless of geographic location. ${ }^{3}$ The Act passed the Senate by a vote of $90-9$, and was seen by human rights activists as a "victory for the rule of law" and a step toward healing the nation's damaged reputation in the eyes of the world. ${ }^{4}$

However, it soon came to light that President Bush had issued a statement contemporaneously with the signing of the bill. In it, Bush declared that "[t]he Executive branch shall construe" the prohibition "in a manner consistent with the constitutional authority of the President to supervise the unitary executive branch and as Commander in Chief and consistent with the constitutional limitations on the judicial power" in

\footnotetext{
Michael T. Crabb. J.D. candidate 2009, University of Kansas School of Law; B.S. 2001, Kansas State University. Many thanks to Professor Richard E. Levy, Joe Bant, and Kelly Foos for helpful comments on early drafts of this piece. Special thanks to Julie and Ethan for your loving support and sacrifices.

1. Abuse of Iraqi POWs by GIs Probed, CBSNews.COM, Apr. 28, 2004, http://www. cbsnews.com/stories/2004/04/27/60II/main614063.shtml.

2. See Richard Cohen, Op-Ed., We Don't Want a Hanoi Hilton, WASH. Post, Oct. 27, 2005, at A27 (discussing a visit to the North Vietnamese prison known as the "Hanoi Hilton" where McCain was held during his five and a half years as a prisoner of war).

3. 42 U.S.C. $\S 2000 \mathrm{dd}(2007)$.

4. Rick Klein \& Charlie Savage, Bush Accedes to McCain in Backing Ban on Torture, Boston Globe, Dec. 16, 2005, at A1.
} 
order to "protect[] the American people from further terrorist attacks.", To many, this signaled that President Bush did not intend to comply with the prohibition. ${ }^{6}$

This episode remains one of the most controversial of Bush's presidency. ${ }^{7}$ At the time, the presidential practice of issuing statements that looked like enforcement disclaimers was largely unheard of in the public sphere. And the idea of the President announcing his intention to construe a statute in a manner consistent with some obscure-sounding political theory such as the "unitary executive" seemed also to be antithetical to what the public had learned in civics class.

This Comment will pull the curtain back on the practice of presidential signing statements to discover that, despite their dubious appearance, they are really inherently innocuous. Furthermore, this Comment will argue that the President is sometimes justified in employing what is known as the avoidance canon in order to construe a statute to avoid an unconstitutional application, and that the presidential signing statement can be a useful vehicle for doing so. In particular, it will argue that careful, comprehensive Executive construction of constitutionally troublesome statutes simultaneously protects the Executive's constitutionally enumerated authorities, respects the role of the Legislature in the enactment process, and many times makes final judicial review of a constitutional violation possible where it otherwise may not be.

\section{The PRESIDENTIAL SIGNING STATEMENT}

A presidential signing statement is simply a short document issued by the President when he signs a bill into law. ${ }^{8}$ The majority of signing statements issued throughout the history of the presidency have been innocuously rhetorical in nature, extolling the virtues of a bill or perhaps

5. Statement on Signing the Department of Defense, Emergency Supplemental Appropriations to Address Hurricanes in the Gulf of Mexico, and Pandemic Influenza Act, 41 WEEKLY COMP. PRES. DOC. 1918, 1919 (Jan. 2, 2006).

6. See, e.g., Editorial, Unchecked Abuse, WASH. POST, Jan. 11, 2006, at A20 (suggesting that "Mr. Bush is planning to ignore it whenever he chooses").

7. See, e.g., Bruce Fein, Commentary, Presidential Power Patois?, WaSH. TIMES, Oct. 23, 2007, at A18 ("Mr. Mukasey denounced torture as unconstitutional, but declined to rebuke President Bush's signing statement issued in conjunction with the Detainee Treatment Act of 2005 ....'); William Fisher, Bush: Uniter, Decider, and Now, Interpreter, ANTIWAR.COM, Feb. 6, 2008, http:// www.antiwar.com/ips/fisher.php?articleid=12317 ("Arguably, the most controversial of Bush's signing statements rejected the so-called McCain Amendment . ....”).

8. Curtis A. Bradley \& Eric A. Posner, Presidential Signing Statements and Executive Power, 23 Const. COMMENT. 307, 308 (2006). 
pointing out its shortcomings. ${ }^{9}$ These statements amount to little more than White House press releases. Other signing statements are more political in nature; they may be intended as a sort of enforcement directive to an Executive Branch agency or as an attempt to influence later judicial interpretation of the statute's meaning. ${ }^{10}$ More controversially, Presidents have issued signing statements in order to express perceived constitutional defects in a bill, ranging from separation of powers concerns to individual rights concerns. ${ }^{11}$ These statements may call on Congress to enact corrective legislation, or they may assert the authority to decline to execute the challenged provision or to execute it in a manner which comports with the Executive's interpretation of the Constitution. ${ }^{12}$ Although signing statements may be rhetorical, political, or constitutional in nature, this Comment will focus solely on the constitutional variety.

\section{A. Brief History}

Article I, section 7 of the U.S. Constitution provides that when a President vetoes a bill, "he shall return it, with his Objections to that House in which it shall have originated."13 There is no constitutional analogue requiring the President to offer any explanation whatsoever when he chooses instead to sign a bill into law. ${ }^{14}$ Yet, Presidents of both parties have made extensive use of rhetorical, political, and constitutional signing statements. ${ }^{15}$ President James Monroe issued what are considered by scholars to be the first two signing statements in 1819 and 1822, respectively. ${ }^{16}$ Neither was issued contemporaneously with the signing of a bill, but both expressed Monroe's intention to interpret an existing law to avoid unconstitutional interference with his Executive prerogatives. ${ }^{17}$ In 1830, President Andrew Jackson became responsible for the first two signing statements issued contemporaneously with the

9. Christopher S. Kelley, The Significance of the Presidential Signing Statement, in EXECUTING THE CONSTITUTION 73, 75 (Christopher S. Kelley ed., 2006).

10. Id. at 74 .

11. Id.

12. Id.

13. U.S. CONST. art. I, § 7, cl. 2 (emphasis added).

14. Christopher N. May, Presidential Defiance of "Unconstitutional" laws: Reviving the Royal Prerogative 72-73 (1998).

15. See id. at $72-75$.

16. Id. at $73 \& 174$ n. 10 .

17. Id. 
signing of the bills to which they were directed. ${ }^{18}$ Congress has always resented this practice - a fact illustrated well by an 1842 episode in which President John Tyler issued a "rather timid signing statement" expressing mild doubt about the validity of a portion of a bill dealing with the apportionment of congressional districts. ${ }^{19}$ A House Select Committee issued a sharp and lengthy protest authored by Tyler's predecessor John Quincy Adams, denouncing the document as "a defacement of the public records and archives" and an "evil example for the future." 20

Despite its deep roots in the nation's history, the issuance of signing statements remained more or less anomalous well into the twentieth century. ${ }^{21}$ By 1950, however, the practice was commonplace. ${ }^{22}$ The average number of signing statements issued per year climbed steadily from almost sixteen during the Truman years to more than forty during Clinton's tenure. ${ }^{23}$ Additionally, "[c]oncurrent with the rise in the number of statements issued, the usage of signing statements to voice constitutional objections to acts of Congress has become increasingly prevalent over the past 60 years." 24

The Reagan Administration was the first to direct an orchestrated effort toward developing the signing statement as a strategic weapon to aggressively protect Executive prerogatives. ${ }^{25}$ One key aspect of this effort was an attempt to establish the signing statement as part of the legislative history of a law, and, in turn, to persuade courts to consider them when interpreting the meaning or constitutionality of statutes. ${ }^{26}$ In 1986, Supreme Court Justice Samuel Alito, then serving as Deputy Assistant Attorney General in the Office of Legal Counsel, drafted a memorandum in which he stated that a primary objective of the Litigation Strategy Working Group "is to ensure that Presidential signing statements assume their rightful place in the interpretation of legislation." 27 Alito argued that because the President's approval of a

8. Id. at 73 \& $174 \mathrm{n} .11$

19. Kelley, supra note 9 , at 75 .

20. Id.; MAY, supra note 14, at 73 (quoting H.R. REP. No. 27-909, at 12 (1842)).

21. MAY, supra note 14 , at 73 .

22. Id.

23. Id. at 74

24. T.J. Halstead, U.S. Congressional Research Service Report for Congress, Presidential Signing Statements: Constitutional and Institutional Implications, No. RL33667, Sept. 17, 2007, at 2-3, available at $\mathrm{http} / / \mathrm{www}$. fas.org/sgp/crs/natsec/RL33667.pdf [hereinafter CRS Report].

25. Christopher S. Kelley, A Matter of Direction: The Reagan Administration, the Signing Statement, and the 1986 Westlaw Decision, 16 WM. \& MARY BILL RTS. J. 283, 284 (2007).

26. CRS Report, supra note 24, at 3.

27. Memorandum from Samuel A. Alito, Jr., Deputy Assistant Att'y Gen., to the Litigation 
bill is just as important in the enactment process as that of the House or Senate, "it seems to follow that the President's understanding of the bill should be just as important as that of Congress." ${ }^{28}$ In December of 1985, Attorney General Edwin Meese III wrote to the West Publishing Company, requesting that the text of presidential signing statements be included in United States Code Congressional and Administrative News ("USCCAN") as part of the legislative history of the Acts of Congress. ${ }^{29}$ West's president agreed, adding that he was "surprised nobody thought of it before." 30

During the Clinton Administration, the Office of Legal Counsel again produced memoranda supporting the issuance of signing statements, but this time asserted a presidential authority to use them as a device to announce an intention to refuse to enforce unconstitutional statutes. ${ }^{31}$ Interestingly, the first of these memoranda characterized the use of signing statements to create legislative history as "much more controversial" than their use to declare a statute unconstitutional and therefore unenforceable. ${ }^{32}$ A subsequent memorandum asserted that the President has an "enhanced responsibility to resist unconstitutional provisions that encroach upon the constitutional power of the Presidency," yet nonetheless acknowledged that the "Supreme Court plays a special role in resolving disputes about the constitutionality of enactments." 33

With this strategic groundwork in place, the stage was set for George W. Bush to make full use of signing statements to defend or expand Executive power by challenging provisions of statutes with perceived constitutional defects. Since taking office, Bush has issued more than 150 signing statements - about twenty-two per year - a rate actually

Strategy Working Group (Feb. 5, 1986), available at http://www.archives.gov/news/samuel-alito/ accession-060-89-269/Acc060-89-269-box6-SG-LSWG-AlitotoLSWG-Feb1986.pdf.

28. Id.

29. Kelley, supra note 25, at 304-05 (citing Letter from Edwin Meese III, U.S. Att'y Gen., to Dwight D. Opperman, President \& Chief Executive Officer, West Publ'g Co. (Dec. 13, 1985), available at http://www.archives.gov/news/samuel-alito/accession-060-89-269/Acc060-89-269-box3 -SG-ChronologicalFile.pdf).

30. Id. (quoting Letter from Dwight D. Opperman, President \& Chief Executive Officer, West Publ'g Co., to Hon. Edwin Meese III, U.S. Att'y Gen. (Dec. 26, 1985), available at http://www. archives.gov/news/samuel-alito/accession-060-89-269/Acc060-89-269-box3-SG-

ChronologicalFile.pdf).

31. CRS Report, supra note 24 , at 6 .

32. The Legal Significance of Presidential Signing Statements, 17 Op. Off. Legal Counsel 131, 131 (1993).

33. Presidential Authority to Decline to Execute Unconstitutional Statutes, 18 Op. Off. Legal Counsel 199, 200-01 (1994). 
lower than that of his immediate predecessors. ${ }^{34}$ However, there are important qualitative differences between Bush's signing statements and those of other Presidents. Bush's signing statements are typified by objections to multiple provisions of each new law, bringing his total number of challenges to discrete provisions of law to more than $1000 .^{35}$ Additionally, Bush's signing statements are much more likely to challenge laws on a constitutional basis. Almost $78 \%$ of Bush's signing statements contain a constitutional objection, ${ }^{36}$ compared with $18 \%$ during the Clinton Administration, ${ }^{37} 54 \%$ during the George H.W. Bush Administration, and $35 \%$ during the Reagan Administration. ${ }^{38}$

\section{B. Controversy}

Despite all of this activity, the signing statement went largely unnoticed by Congress and the general public until it was thrust into the national spotlight in April of 2006 when a front-page Boston Globe article asserted that President Bush had "quietly claimed the authority to disobey more than 750 laws enacted since he took office." ${ }^{39}$ This story sparked a national controversy, fueled by an already-widespread belief that "the Bush administration had taken extreme positions on executive authority in its legal defense of its war-on-terror policies." 40 The article also highlighted Alito's signing statement memorandum, ${ }^{41}$ which had surfaced during his Senate confirmation hearings earlier that year, thus implicating the Supreme Court in the turmoil. ${ }^{42}$ Adding to the suspicion of a disturbance in the constitutional separation of powers was the fact

34. President Clinton issued 381 (47.6 per year), President George H.W. Bush issued 228 (57 per year), and President Reagan issued 250 (31.3 per year). CRS Report, supra note 24, at 3, 5-6, 9.

35. Id. at 9 .

36. Id.

37. Id. at 6 .

38. MAY, supra note 14 , at 74

39. Charlie Savage, Bush Challenges Hundreds of Laws, Boston GloBe, Apr. 30, 2006, at A1. Savage was later awarded the 2007 Pulitzer Prize for National Reporting for this story. David Mehegan, Globe Writer Wins Pulitzer for National Reporting, Boston GloBe, Apr. 17, 2007, at A1.

40. Bradley \& Posner, supra note 8, at 309. See, e.g., Editorial, History Lesson: A Forgotten Injustice Echoes Today, SACRAMENTO BEE, May 4, 2006, at B8 (claiming Bush will "do what he wants and call it legal"); Susan Page, Power Play: Congress Pushing Back Against Bush's Expansion of Presidential Authority, USA TODAY, June 6, 2006, at 1A ("Congress and the courts are beginning to push back against what has been the greatest expansion of presidential powers in a generation or more"); Editorial, Veto? Who Needs a Veto?, N.Y. TIMES, May 5, 2006, at A22 (arguing that Bush "placed his imperial vision of the presidency over the will of America's elected lawmakers").

41. See supra note 27 and accompanying text.

42. Savage, supra note 39 
that President Bush, at that time, had yet to exercise his veto powerbecoming the first President in modern history to serve an entire term without doing so. ${ }^{43}$ Had the President abandoned the veto in favor of a more powerful tool in the signing statement?

In June of 2006, the American Bar Association appointed a task force to provide a "scholarly analysis of the utility of presidential signing statements and how they comport with the Constitution and enacted law." ${ }^{44}$ The task force concluded that the issuance of signing statements claiming the President's authority to "state the intention to disregard or decline to enforce all or part of a law he has signed, or to interpret such law in a manner inconsistent with the clear intent of Congress" was "contrary to the rule of law and our constitutional system of separation of powers." 45 The report urged Congress to enact legislation to curb the President's issuance of signing statements and to enable members of Congress to seek judicial review in any instance in which the President expressed the intention to interpret a statutory provision in a manner inconsistent with congressional intent. ${ }^{46}$

On June 27, 2006, Senator Patrick Leahy remarked before the Senate Judiciary Committee that signing statements posed "a grave threat to our constitutional system of checks and balances" and that President Bush had "used his signing statements as a de facto line-item veto to cherrypick which laws he will enforce in a manner not contemplated by our Constitution." ${ }^{\text {"4 }}$ Hearkening back to John Quincy Adams's hyperbolic assessment, Leahy further declared the signing statement a "diabolical device" which "intrude[s] upon the legislative function and also upon the constitutional role of our courts." 48 Several pieces of legislation have been proposed consistent with the ABA Task Force's recommendation, each attempting to regulate the practice in its own way, but none has yet been enacted. ${ }^{49}$

43. Id.

44. AMERican Bar AsSOCIATION, Report: TASK ForCe ON PRESidential Signing Statements AND THE SEPARATION OF POWERS DOCTRINE 4 (2006), available at http://www. abanet.org/op/signingstatements/aba_final_signing_statements_recommendation-report_7-24-06.pdf [hereinafter ABA REPORT].

45. Id. at 5 .

46. Id. at 1 .

47. Presidential Signing Statements: Hearing Before the Comm. on S. Judiciary, 110th Cong. (2006) [hereinafter Hearing] (statement of Sen. Patrick Leahy).

48. Id.

49. See, e.g., Presidential Signing Statements Act of 2007, H.R. 3045, S. 1747, 110th Cong. (2007) (prohibiting any court from relying upon or deferring to a signing statement as a source of authority and granting a congressional right to participate as amicus curiae in any action regarding the construction or constitutionality of any federal statute to which a signing statement was issued); 
Such congressional disdain may be attributable to the fact that signing statements are commonly misconceived as a type of power to dispense with the law or an underhanded form of the unconstitutional line-item veto. The Supreme Court struck down the Line Item Veto Act in Clinton v. City of New York as a violation of the Presentment Clause of the Constitution. ${ }^{50}$ The Act purported to confer upon the President the authority to "cancel in whole" certain spending line items of large appropriations bills. ${ }^{51}$ Although both Congress and the President desired this arrangement, the Court held that these line-item cancellations were tantamount to impermissibly conferring upon the Executive the congressional authority to amend or repeal statutes. ${ }^{52}$

However, unlike line-item vetoes, signing statements have no binding legal force or effect. ${ }^{53}$ "They have the same legal significance as other mechanisms the President could use to deliver the same message, such as a speech, a radio address, or an answer to a question at a press conference: none at all." ${ }^{, 54}$ Thus, although the enforcement intentions revealed in a signing statement may be problematic or even unconstitutional, the signing statement is not itself intrinsically unlawful. A recent Congressional Research Service report concluded the same, stating that "[i]f an action taken by a President in fact contravenes legal or constitutional provisions, the illegality is not augmented or assuaged merely by the issuance of a signing statement." 55 In this way, "[t]he critics confuse the medium and the message." 56 Furthermore, when the President signs a bill, all of it becomes positive law, notwithstanding the issuance of a signing statement declaring a portion of it unconstitutional and unenforceable as written. ${ }^{57}$ When a bill is signed into law, "[i]t binds the conduct of the executive branch actors in the absence of a

Congressional Lawmaking Authority Protection Act of 2007, H.R. 264, 110th Cong. (2007) (prohibiting the use of funds made available to the Executive Office of the President from being used for producing, publishing, or disseminating signing statements); Presidential Signing Statements Act of 2006, S. 3731, 109th Cong. (2006) (conferring standing upon Congress's members to challenge signing statements in court); H.R.J. Res. 87, 109th Cong. (2006) (requiring the President to notify Congress anytime he issues a signing statement).

50. 524 U.S. 417, 448 (1998).

51. Id. at 436 .

52. See id. at 448

53. John F. Cooney, Signing Statements: A Practical Analysis of the ABA Task Force Report, 59 ADMIN. L. REV. 647, 649 (2007).

54. Id.

55. CRS Report, supra note 24 , at 15.

56. Bradley \& Posner, supra note 8 , at 362 .

57. David Barron et al., Untangling the Debate on Signing Statements, Georgetown LAW FACULTY BLOG, July 31, 2006, http://www.gulcfac.typepad.com/georgetown_university_law/2006/ 07/thanks_to_the_p.html. 
presidential directive not to enforce it, and it can and will be enforced by future Presidents who disagree" with any signing statement issued by a predecessor. $^{58}$

Of course, it must be acknowledged that although signing statements lack any legally binding effect, they very well may carry implicit binding effect on Executive officials who, serving at the pleasure of the President, are likely to be especially attentive to White House statements relevant to their duties. This idea is developed more fully later.

It is frequently reported that President Bush's signing statements declare an intention to ignore or set aside a provision of law. ${ }^{59}$ However, after an exhaustive study, the Congressional Research Service found that "in almost all instances where President Bush has raised a constitutional concern or objection, he has stated that he will construe the provision at issue in a manner that will avoid his concerns." "60 "In some statements, ... . President Bush has declared that he would comply with the provision at issue 'as a matter of comity.",61 " $[\mathrm{I}] \mathrm{t}$ is exceedingly rare for a President to make a direct announcement that he will categorically refuse to enforce a provision he finds troublesome." ${ }^{~} 2$ A casual perusal through the signing statements issued by President Bush reveals a ubiquitous, repetitive refrain: "the Executive branch shall construe." Whether intentionally or not, the Bush Administration appears to be couching constitutional objections in some semblance of the Judiciary's canon of constitutional avoidance. A fuller inspection of this canon is helpful here.

58. Id.

59. See, e.g., Opinion, End the Use of Signing Statements, The Harvard Crimson, Nov. 26, 2007, available at http://www.thecrimson.com/article.aspx? $\mathrm{ref}=520930$ (describing signing statements as a device "by which the president instructs the executive branch to effectively ignore some parts of a bill"); Charlie Savage, Bush Asserts Authority to Bypass Defense Act, BOSTON GloBE, Jan. 30, 2008, at 1A ("President Bush this week declared that he has the power to bypass four laws...."); Savage, supra note 39 ("President Bush has quietly claimed the authority to disobey more that 750 laws ....”); Editorial, The Fine Print, N.Y. TiMES, Jan. 30, 2008, at A22 ("Mr. Bush has issued hundreds of these insidious documents declaring that he had no intention of obeying a law that he had just signed.").

60. CRS Report, supra note 24, at 10.

61. Id.

62. Id. at 24 . 


\section{THE AVOIDANCE CANON}

The canon of constitutional avoidance ${ }^{63}$ is a rule of judicial construction that holds that where "a statute is susceptible of two constructions, by one of which grave and doubtful constitutional questions arise and by the other of which such questions are avoided, [a court's] duty is to adopt the latter." ${ }^{24}$ The avoidance canon "has been 'repeatedly affirmed' to the point that it has achieved rare status as a 'cardinal principle' that is 'beyond debate." 65 Virtually no Supreme Court Justice has ever voiced doubts about its legitimacy. ${ }^{66}$

The avoidance canon is rooted primarily in prudential judicial restraint influenced by the principles of separation of powers and respect for the other branches of government. ${ }^{67}$ "The Court has said that because Congress 'is bound by and swears an oath to uphold the Constitution,' the Court is obliged to indulge any possible construction that avoids constitutional difficulties." Court in order to ameliorate worries about the counter-majoritarian institution of judicial review which must occasionally reject the product of the democratic lawmaking process. ${ }^{69}$ In other words, the avoidance canon is designed to be an express acknowledgement of legislative supremacy within the lawmaking sphere. ${ }^{70}$

Justice Breyer recently elaborated for the Court: "The doctrine seeks in part to minimize disagreement between the branches by preserving congressional enactments that might otherwise founder on constitutional objections.... [T] he doctrine serve[s] [the] basic democratic function of maintaining a set of statutes that reflect, rather

63. The canon of constitutional avoidance is sometimes also referred to as the doctrine of constitutional doubt. For the purposes of this Comment, the terms are synonymous.

64. Harris v. United States, 536 U.S. 545, 555 (2002) (quoting U.S. ex rel. Att'y Gen. v. Del. \& Hudson Co., 213 U.S. 366, 408 (1909)).

65. William K. Kelley, Avoiding Constitutional Questions as a Three-Branch Problem, 86 CORNEll L. REV. 831, 832 (2001) (quoting Jones v. United States, 526 U.S. 227, 239 (1999); Edward J. DeBartolo Corp. v. Fla. Gulf Coast Bldg. \& Constr. Trades Council, 485 U.S. 568, 575 (1988)).

66. Id. at 833 .

67. Lisa A. Kloppenberg, Avoiding Constitutional Questions, 35 B.C. L. REV. 1003, 1047-48 (1994).

68. Kelley, supra note 65, at 844 (quoting DeBartolo Corp., 485 U.S. at 575).

69. Id.

70. See id. at $843-46$. 
than distort, the policy choices that elected representatives have made." $" 1$

Nevertheless, the avoidance canon "does not give a court the prerogative to ignore the legislative will,",72 the Supreme Court has stated that "[w]e cannot press statutory construction "to the point of disingenuous evasion' even to avoid a constitutional question." ${ }^{, 73}$ To put it plainly, if the statute at issue is not susceptible to a saving construction, only then will the Court rule on the constitutional issue. Just how serious the constitutional problem must be before the avoidance canon is triggered, and just how plausible the saving construction must be after the canon has been employed, are questions which seem to be resolved pragmatically with each case.

Although the Court often cites deference to Congress as justification for the avoidance canon, it is also mindful of the finality of its decisions. "If the Court renders a final, binding conclusion as to constitutional interpretation each time it speaks on a constitutional issue, the arduous task of amending the Constitution may provide the only counter to the Court's ruling.", 74

Critics of the avoidance canon have asserted that it does not always serve the underlying value of legislative supremacy. ${ }^{75}$ "First, given the complexities of the legislative process, it might well be that Congress would want a statute to be construed in a manner that makes the constitutional question unavoidable." ${ }^{, 76}$ Thus, in this context, it is no act of deference to construe a statute in a manner contrary to the expressed legislative intent. Second, in a related argument, critics complain that whenever the Court purports not to decide a constitutional question, it is in fact relying upon previously decided constitutional questions. ${ }^{77}$ In this way, the Legislature has a very difficult time challenging the Court to consider budging from static constitutional moorings.

Whatever its shortcomings, the fact remains that the avoidance canon is a deeply entrenched judicial value in our system of checks and balances. This Comment will argue that the framework of the avoidance

71. Id. at 844 (quoting Almendarez-Torres v. United States, 523 U.S. 224, 238 (1998)).

72. Commodity Futures Trading Comm'n v. Schor, 478 U.S. 833, 841 (1986).

73. United States v. Locke, 471 U.S. 84, 96 (1985) (quoting George Moore Ice Cream Co. v. Rose, 289 U.S. 373, 379 (1933)).

74. Kloppenberg, supra note 67, at 1036.

75. Kelley, supra note 65 , at 846 .

76. Id.

77. Id. at 860 
canon may be successfully transplanted to the Executive Branch in the vehicle of presidential signing statements where it may be used to inform enforcement decisions regarding constitutionally troublesome provisions of law. Because the Executive's constitutional interpretations do not share the binding finality of the judiciary's decisions, and because sufficient safeguards exist to prevent the canon's abuse, the President may employ a more liberal application of the avoidance canon than may the courts - that is, the President may more freely express constitutional doubt regarding statutes and may offer more creative saving interpretations which bear a more attenuated resemblance to the congressional intent. This Comment will explore the institutional checks which prevent a President from misusing this device, as well as the institutional incentives in place for the President to use it with discipline and restraint. Executive application of the avoidance canon in presidential signing statements allows the fullest constitutional implementation of the Acts of Congress while simultaneously affording the Executive the fullest control over its legitimate enforcement prerogatives.

\section{THE BASIS FOR EXECUTIVE CONSTITUTIONAL INTERPRETATION}

The avoidance canon was developed by the judiciary as a prudential restraint on its exclusive province "to say what the law is.", Nevertheless, "Presidents often avoid constitutional problems, as they should, through their interpretation of ambiguous statutes or through the exercise of enforcement discretion." ${ }^{, 79}$ The question remains whether it is a desirable or legal practice for the President to interpret statutes to avoid constitutional difficulties when the statute unambiguously mandates the Executive to do or refrain from doing something. There exists abundant academic debate regarding whether a President possesses the constitutional authority to decline to enforce, or enforce according to his own saving interpretation, a constitutionally defective statute that admits of no ambiguity or prosecutorial discretion. ${ }^{80}$ Professor Dawn Johnsen, constitutional scholar and former acting assistant attorney general for the Office of Legal Counsel, believes that "most of the academic literature fairly and usefully can be described as following one of two approaches: mandatory enforcement or routine non-enforcement of constitutionally

78. Marbury v. Madison, 5 U.S. (1 Cranch) 137, 177 (1803).

79. Dawn E. Johnsen, Presidential Non-Enforcement of Constitutionally Objectionable Statutes, 63 LAW \& CONTEMP. PROBS. 7, 9 (2000).

80. Id. at 14 
objectionable statutes." ${ }^{\text {}}$ The following discussion will borrow her framework.

\section{A. Mandatory Enforcement Regardless of Constitutionality}

"One approach to presidential non-enforcement interprets the Constitution as requiring the President to execute acts of Congress, unless directed otherwise by a court of law, even when the President believes a law violates the Constitution." 82 This position is readily apparent in the report of the ABA Task Force on Signing Statements, which concluded that "[b]ecause the 'take care' obligation of the President requires him to faithfully execute all laws, his obligation is to veto bills he believes are unconstitutional. He may not sign them into law and then emulate King James II by refusing to enforce them." 83 Christopher May, constitutional law scholar, has similarly likened presidential non-enforcement of laws under any circumstance as a resurrection of "the suspending power, a royal prerogative that was abolished in England by the Bill of Rights of 1689 after centuries of struggle between Parliament and the Crown." ${ }^{" 84}$

This position is grounded on a literal reading of the Take Care Clause of the Constitution, which provides that the President must "take Care that the Laws be faithfully executed." 85 The Presentment Clause is similarly straightforward, providing that all bills, before becoming law, must be presented to the President, and "[i]f he approve he shall sign it, but if not he shall return it, with his Objections to that House in which it shall have originated." 86 This clause goes on to qualify the President's veto by providing that it can be overridden by a two-thirds majority of both houses. ${ }^{87}$ Neither of these constitutional provisions seems to contemplate the possibility of a President signing a bill and then refusing to enforce it or enforcing it according to an interpretation saving it from perceived constitutional doubt.

Proponents of the mandatory enforcement view find support in various statements by the Supreme Court. In Youngstown Sheet \& Tube

81. Id. Professor Johnsen adds the caveat that she is not exhaustively "addressing all views or some significant subtleties in views." Id.

82. Id.

83. ABA REPORT, supra note 44 , at 19.

84. MAY, supra note 14 , at 153 . The suspending power was an exercise of royal authority to suspend the execution of a law without the consent of Parliament.

85. U.S. CONST. art. II, $\S 3$.

86. U.S. CONST. art. I, $\S 7$, cl. 2.

87. Id. 
Co. v. Sawyer, also known as the Steel Seizure case, the Court wrote that "the President's power to see that the laws are faithfully executed refutes the idea that he is to be a lawmaker. The Constitution limits his functions in the lawmaking process to the recommending of laws he thinks wise and the vetoing of laws he thinks bad." 88 Similarly, in holding the line-item veto unconstitutional, the Court in Clinton v. City of New York stated that "[o]ur first President understood the text of the Presentment Clause as requiring that he either 'approve all the parts of a Bill, or reject it in toto." $" 89$

While compelling, neither of the above statements was essential to the holding, and are best viewed as dicta. The only federal appellate court to squarely consider the legitimacy of presidential non-enforcement based on a perceived constitutional defect was the Ninth Circuit in Lear Siegler, Inc. v. Lehman. ${ }^{90}$ There, the court found that President Reagan's asserted authority to decline to enforce provisions of the Competition in Contracting Act on constitutional grounds was tantamount to a "de facto line item veto." "The court further found that by refusing to enforce the provision at issue, the President unconstitutionally assumed the power of judicial review, a role constitutionally assigned to the judicial branch." 92

Despite this rather clear rationale, Presidents of both parties have consistently taken the position that where a statute is unconstitutional, it is the President's prerogative-perhaps even his duty-to refuse to enforce it. ${ }^{93}$

\section{B. Routine Non-Enforcement of Constitutionally Troublesome Law}

At the other end of the spectrum is the position that Presidents should routinely refuse to enforce any statute with constitutional defects. This approach acknowledges that the Take Care Clause requires the President to ensure the faithful execution of the laws, but emphasizes that the Constitution is among the "laws" that the President is bound to

\footnotetext{
88. 343 U.S. 579,587 (1952).

89. 524 U.S. 417, 440 (1998) (quoting 33 Writings OF GEORgE WASHINGTON 96 (J. Fitzgerald ed., 1940)).

90. Johnsen, supra note 79, at 14-15 (citing Lear Siegler, Inc. v. Lehman, 842 F.2d 1102 (9th Cir. 1988), withdrawn in part on other grounds, 893 F.2d 205 (9th Cir. 1989) (en banc) (per curiam)).

91. Id. at 15 (citing Lear Siegler, Inc., 842 F.2d at 1124).

92. Id. (citing Lear Siegler, Inc., 842 F.2d at 1125).

93. Neil Kinkopf, Signing Statements and the President's Authority to Refuse to Enforce the Law, ADVANCE, Spring 2007, at 5, 7, available at http://www.acslaw.org/node/2965.
} 
faithfully execute. ${ }^{94}$ Proponents of this view find support in the Supremacy Clause, which provides that the Constitution "shall be the supreme Law of the Land," it. When read together with the President's constitutionally prescribed oath to "preserve, protect and defend the Constitution," "96 proponents conclude that the proper Executive resolution of a conflict between a statute and the Constitution is that "[t]he President must heed and execute the Constitution, the supreme law of our Nation.' Indeed, 'an unconstitutional statute... is simply not a law at all,' and therefore "cannot be one of the "Laws" that the President must faithfully execute." "97 Thus, the argument goes, "[f]or a President to choose to enforce a statute he believed was unconstitutional would constitute a dereliction of his constitutional obligation." 98

This view has deep historical roots. President Thomas Jefferson, for example, offered the following explanation for his choice to order the cessation of all prosecutions and to pardon all of those convicted under the Sedition Act: "'the opinion which give to the judges the right to decide what laws are constitutional, and what are not, not only for themselves in their own sphere of action, but for the Legislature \& Executive also, in their spheres, would make the judiciary a despotic branch." "99 The Supreme Court finally confirmed the unconstitutionality of the Sedition Act 163 years later. ${ }^{100}$ Judge Frank Easterbrook of the Seventh Circuit Court of Appeals argues that President Jefferson correctly

contended that no law may go into force unless all three branches agree that it is constitutional. Each, acting within its sphere, has the power to say no: Congress not to enact, the President not to approve in his

94. Johnsen, supra note 79 , at 16 .

95. U.S. CONST. art. VI, cl. 2.

96. U.S. CONST. art. II, § 1, cl. 7.

97. Johnsen, supra note 79, at 17 (quoting Issues Raised by Provisions Directing Issuance of Official or Diplomatic Passports, 16 Op. Off. Legal Counsel 18, 32 (1992)).

98. Id. at 19 .

99. Frank H. Easterbrook, Presidential Review, 40 CASE W. RES. L. REV. 905, 909 (1990) (quoting 8 The Writings of THOMAS JeFFERSON 310-11 (P. Ford ed., 1897) (letter to Abigail Adams dated Sept. 11, 1804)).

100. Barron et al., supra note 57. See N.Y. Times Co. v. Sullivan, 376 U.S. 254, 276 (1964) ("Although the Sedition Act was never tested in this Court, the attack upon its validity has carried the day in the court of history. Fines levied in its prosecution were repaid by Act of Congress on the ground that it was unconstitutional.”). 
legislative role or enforce in his executive role, and the Court to set aside. $^{101}$

Easterbrook sums up his view of the Executive's enforcement power in this way: "[t]o apply the rules includes the power to interpret them.,"102 These views are largely premised on the political theory of departmentalism or coordinancy enunciated in Federalist No. 49, which generally holds that all three branches are equally charged with the responsibility to interpret and uphold the Constitution. ${ }^{103}$

This position finds support in a number of Supreme Court statements as well. In Myers v. United States, President Wilson had defied the Tenure in Office Act prohibiting him from removing postmasters without Senate approval. ${ }^{104}$ Although President Wilson believed the statute to be unconstitutional, there was no Supreme Court precedent on point at the time he acted to support his view. ${ }^{105}$ Interestingly, the House had impeached (and the Senate had come within one vote of convicting) President Andrew Johnson some sixty years earlier for violating the same statute. $^{106}$ The Court ultimately struck down the Act as an unconstitutional encroachment of the Executive's removal powers. ${ }^{107}$ In the opinion, "no member of the Court... suggested that Wilson overstepped his constitutional authority — or even acted improperly—by refusing to comply with a statute he believed was unconstitutional."108 Furthermore, had Wilson followed the mandatory enforcement approach by obtaining Senate approval before terminating the postmaster, there would have been no basis for the Myers lawsuit and thus no opportunity for judicial review and invalidation of this unconstitutional Act. ${ }^{109}$

The Court in INS v. Chadha ${ }^{110}$ acknowledged with apparent approval the "'not uncommon"" practice of Presidents approving and later challenging legislation "containing parts which are objectionable on

\footnotetext{
101. Easterbrook, supra note 99 , at 910.

102. Id. at 914 .

103. See The Federalist No. 49 (James Madison).

104. 272 U.S. 52, 107-08 (1926).

105. Presidential Authority to Decline to Execute Unconstitutional Statutes, supra note 33, at

106. Johnsen, supra note 79 , at 8 .

107. Myers, 272 U.S. at 176.

108. Presidential Authority to Decline to Execute Unconstitutional Statutes, supra note 33, at

109. Kinkopf, supra note 93, at 7.

110. 462 U.S. 919 (1983).
} 201. 201. 
constitutional grounds.",111 The Chadha court invalidated as unconstitutional the congressional practice of enacting legislative veto provisions - provisions requiring single-House or committee approval of Executive agency promulgations - after no fewer than eleven Presidents had gone on record challenging the practice. In a similar statement in Freytag v. Commissioner, four Justices agreed in a concurrence by Justice Scalia that the Constitution provided the President with various means to resist legislative encroachment, including "the power to veto encroaching laws... or even to disregard them when they are unconstitutional." 112

Although these statements lend credence to the assertion that a President may decline to enforce a constitutionally objectionable statute, they beg the question: why not instead use the traditionally contemplated power of the veto in order to avoid the problem altogether? One explanation is that a President may sometimes be faced with a statute he believes to be unconstitutional but which he did not have an opportunity to veto because it predates his presidency. Another possibility is that a statute may seem perfectly acceptable on its face, but an unusual scenario causes it to be unconstitutional in only a certain unforeseen application. A third, and significant, factor is the increasingly frequent enactment of omnibus legislation containing numerous unrelated provisions. ${ }^{113}$ This type of legislation makes it practically impossible for Presidents to veto provisions they find unconstitutional without sacrificing other unobjectionable and important-even vital-provisions. ${ }^{114}$ In this way, the Legislature has indirectly diminished the power of the veto. For example, "Congress has enacted hundreds of legislative vetoes since Chadha, and not even members of Congress expect the President to veto such legislation or to enforce the patently unconstitutional legislative veto provisions." 115

The primary difficulty with this position is that it assumes that the President's ability to interpret the Constitution is infallible, or at least superior to that of Congress's. This conflicts with the generally held assumption that the passage of an act is a de facto congressional determination of its constitutionality. ${ }^{116}$ But because members of both

\footnotetext{
111. Barron et al., supra note 57 (quoting Chadha, 462 U.S. at 942 n.13).

112. 501 U.S. 868, 906 (1991) (Scalia, J., concurring).

113. Barron et al., supra note 57.

114. Johnsen, supra note 79, at 33 .

115. Kinkopf, supra note 93, at 7 (citing Louis Fisher, U.S. Congressional Research Service Report for Congress, Legislative Vetoes After Chadha, No. RS22132, May 2, 2005).

116. Johnsen, supra note 79, at 17.
} 
branches are sworn to uphold the Constitution, a rigid framework whereby the President must either enforce all laws, regardless of constitutionality, or routinely refuse to enforce all laws of questionable constitutionality, is unworkable.

\section{A Middle Road: Executive Application of the Avoidance Canon}

Professor Johnsen concludes that "[t]he President does not most faithfully execute the laws either by invariably refusing to enforce statutes based solely on his independent views of what the Constitution means or by enforcing all statutes regardless of their constitutional infirmities."117 Rather, Presidents confronted with the prospect of enforcing constitutionally objectionable laws should be guided by two principles. ${ }^{118}$ "First, the President must enforce the laws in a manner that preserves and respects the integrity of the lawmaking process as set forth in Article I.... Second, the President's non-enforcement decisions must promote not the President's own constitutional views in isolation, but the Constitution itself ...".119 Disciplined Executive application of the time-honored avoidance canon, as discussed below, is an attractive middle road which satisfies both principles.

\section{Application of the AVoidance CANON In PREsidential Signing STATEMENTS}

Signing statements are a natural device by which a President may express an intention to construe a statute so as to avoid constitutional infirmity. Their non-binding nature provides flexibility to allow the statute to be enforced as written as long as a situation does not arise in which the constitutional defect is implicated. Their public nature promotes dialogue and accountability. The proper application of the avoidance canon in the Executive realm depends largely on the nature of the constitutional concern, particularly whether the statute encroaches into Executive authority.

117. Id. at 22 .

118. Id. at 29 .

119. Id. 


\section{A. Addressing Institutional or Separation of Powers Concerns}

Despite well-settled Supreme Court precedent that legislative veto provisions violate the Presentment and Bicameralism Clauses of the Constitution, "to this day a surprising number of statutes enacted by Congress attempt to require the approval of a congressional committee before execution of a law."120 Legislative veto provisions remain so common that they are one of the most frequent objections raised by President Bush in his signing statements. ${ }^{121}$ If the President is presented with one of these provisions alone, he would, and should, almost certainly veto it. This would be the action most in conformity with the lawmaking process as set forth in Article I. However, when a veto is impractical, as in the case of omnibus legislation, refusal to enforce such legislative provisions seems perfectly reasonable. The Bush Administration typically handles legislative veto provisions in signing statements with language that construes the provision as requiring committee notification rather than approval before execution of a law. ${ }^{122}$ In this way, the provision is given the fullest effect possible under the Constitution rather than simply being ignored. The legislative committee members receive at least the information they desire, and the Executive retains its prerogatives.

However, most perceived encroachments into Executive authority have not been as squarely resolved by the Supreme Court as the legislative veto issue. The President has a legitimate interest in seeing to it that he does not acquiesce in the unconstitutional erosion of Executive authority. Presidential acquiescence to statutory provisions which intrude upon traditionally exclusive presidential domain (such as the removal power, the Commander-in-Chief authority, or the responsibility for directing the nation's foreign affairs) may lead to undue difficulty in later restoring those powers. "The presumption of validity which applies to legislation generally is fortified by acquiescence continued through the years." "23 Likewise, "a 'universal and long-established' tradition of prohibiting certain conduct creates a 'strong presumption' that the prohibition is constitutional." "124

120. Hearing, supra note 47 (statement of Michelle Boardman, Deputy Assistant Attorney General).

121. Id.

122. CRS Report, supra note 24 , at 20.

123. Life \& Cas. Ins. Co. of Tenn. v. McCray, 291 U.S. 566, 572 (1934).

124. Republican Party of Minn. v. White, 536 U.S. 765, 785 (2002). 
"The recognition that the President must uphold the Constitution and that an unconstitutional law is 'no law at all' is, however, insufficient to establish presidential authority to disregard 'unconstitutional' laws, for it begs a critical question: 'unconstitutional' in whose view?"125 In the absence of a clear Supreme Court pronouncement of the boundary between Legislative and Executive power, it does not appear that the Executive is in any better position to determine the constitutionality of a law than the presumably conscientious Congress which enacted it.

This is precisely the reason that careful application of the avoidance canon is desirable. Presidential compliance with a potentially encroaching law may be a dereliction of duties to the office. Conversely, to entirely ignore the law violates the fundamental respect owed to the Legislature and the Article I process of enacting laws. The President must articulate his constitutional objections in a manner that demonstrates an effort to promote a fair reading of the Constitution, and not simply the President's own constitutional views in isolation.

President Bush has made steps in this direction by stating in his signing statements that he will construe troublesome statutes in such a way as to avoid constitutional difficulties. However:

[T] he large bulk of the signing statements the Bush II Administration has issued to date do not apply particularized constitutional rationales to specific scenarios, nor do they contain explicit, measurable refusals to enforce a law. Instead, the statements make broad and largely hortatory assertions of executive authority that make it effectively impossible to ascertain what factors, if any, might lead to substantive constitutional or interpretive conflict in the implementation of an act. ${ }^{126}$

President Bush and subsequent Presidents would benefit by developing language in each signing statement describing with specificity the Executive authority they believe is being threatened. Additionally, the signing statement should precisely and comprehensively describe the authority's grounding in the Constitution or Supreme Court precedent. The signing statement should describe with particularity the manner by which the offending statute violates these principles. Finally, it should set out a plausible saving construction that conforms best to the original congressional intent for the statute.

125. Johnsen, supra note 79 , at 17.

126. CRS Report, supra note 24, at 11. 
The President should be mindful of the possibility of justiciability ${ }^{127}$ whenever construing a statute in this way, with a strong preference for taking the action that makes judicial review most likely. "[J]udicial review of statutes generally fosters better constitutional outcomes and is more consistent with the constitutional allocation of lawmaking powers." 128 For example, compliance with a legislative veto provision, although against Executive policy, provided a justiciable case or controversy allowing judicial review in Chadha. Conversely, noncompliance with the Tenure in Office Act as an intrusion on the President's removal power provided a justiciable case or controversy making judicial review possible in Myers. In either situation, the President creates opportunity for "further dialogue among the branches in the context of litigation" 129 by avoiding constitutional doubt. Because it is the exclusive province of the judiciary "to say what the law is," 130 the President should seek out judicial review of potentially unconstitutional legislative encroachment whenever possible by taking the action that will most likely create a justiciable case or controversy.

Still, "[a] relatively small number of statutes will be nonjusticiable whether or not the President enforces them."131 Most of these situations involve the allocation of constitutional powers between the branches, particularly in the areas of foreign affairs and the Commander-in-Chief power where there is not likely to be an injured U.S. citizen with standing to sue for a violation of statutory or constitutional rights caused by the Executive's enforcement choices. ${ }^{132}$ "When barriers to judicial review prevent the courts from providing a check on constitutionally objectionable statutes, and litigation is unavailable as a forum for further dialogue, the President should play an enhanced role in protecting the constitutional structure and the public from the effects of unconstitutional laws."133 In other words, the risk of harm to the nation from enforcing unconstitutional laws is greater than the risk of harm to the balance of powers from disturbing the congressional prerogative.

127. Justiciability is the quality of being suitable for adjudication by a court. Courts commonly require a concrete case or controversy and proper standing to sue. Courts usually will not issue advisory opinions, nor will they rule on political questions or on issues which are moot or not yet ripe. See generally 13 Charles Alan Wright, Arthur R. Miller \& EdWard H. Cooper, FEDERAL PRACTICE AND PROCEDURE $§ 3529$ (2007).

128. Johnsen, supra note 79 , at 48 .

129. Id.

130. Marbury v. Madison, 5 U.S. (1 Cranch) 137, 177 (1803).

131. Johnsen, supra note 79, at 49.

132. Id.

133. Id. (emphasis added). 
As mentioned previously, the President is not necessarily a more adept arbiter of constitutionality than Congress. Because the President is susceptible to political pressures, there exists a risk that he might manipulate statutory construction to serve his own interests above the mandates of the Constitution. But Congress is not left without powerful tools with which to check presidential abuses of this type.

Congress has the power to subpoena Executive officials to testify regarding the implementation of laws at oversight hearings. ${ }^{134}$ Failure to appear may be rebuked with citations for contempt of Congress. ${ }^{135}$ Besides being time-consuming, the hearings are also conducted publicly, forcing the Executive to think carefully about how it wishes to be portrayed to the public regarding its enforcement of the laws. In order to preserve the separation of powers balance, Congress is duty-bound to use its oversight power to check potential Executive abuses of power. ${ }^{136}$ Evidence indicates that Congress may have neglected this duty of oversight during the George W. Bush presidency to some extent; at least while the Republicans controlled Congress: "Just one committee in the House of Representatives - the Government Reform Committee'issued 1,052 subpoenas to probe alleged misconduct' by the Clinton Administration at a cost of over $\$ 35$ million while the same committee issued just 'three subpoenas to the Bush Administration.","137 Thus, if President Bush has indeed misused the signing statement to improperly aggrandize Executive power, a lapse of congressional attention may be at least partially to blame.

A perhaps even more powerful congressional weapon is the carte blanche power of the purse. ${ }^{138}$ Congress may refuse, as it wishes, to enact appropriations bills or may withhold funding for a key Executive agency or department. ${ }^{139}$ The following anecdote illustrates an occasion when Congress exercised this very power to cause the Reagan

134. Christopher S. Kelley, Who's at Fault Here? The Bush Administration, Presidential Power, and the Signing Statement, MSL L. REV. (forthcoming) (manuscript at 14, available at http://ssrn.com/abstract=976235).

135. 2 U.S.C. $\S 192$ (2000). See generally Morton Rosenberg \& Todd B. Tatelman, U.S. Congressional Research Service Report for Congress, Congress's Contempt Power: Law, History, Practice, and Procedure, No. RL34097, July 24, 2007, available at http://www.fas.org/ $\mathrm{sgp} / \mathrm{crs} / \mathrm{misc} / \mathrm{RL} 34097$.pdf (analyzing the procedures associated with the congressional contempt power).

136. Kelley, supra note 134 , at 14 .

137. Id. (quoting Dana Milbank, Bush's Fumbles Spur New Talk of Oversight on the Hill, WASH. Post, Dec. 18, 2005, at A7).

138. Easterbrook, supra note 99, at 912.

139. Kelley, supra note 134, at 14. 
Administration to back down from a position it had taken in a signing statement regarding the unconstitutionality of a statute:

In 1984 the Reagan administration signed into law the "Deficit Reduction Act of 1984," and in the signing statement, it objected to executive authority bestowed upon the Comptroller General, an agent of Congress. A provision of the law, known as the "Competition in Contracting Act," gave the Comptroller General the power to withhold appropriated money in government contracting if one party felt that it deserved to win a contract that it had lost. In addition to the signing statement, the Justice Department issued a legal memorandum defending the president's challenge, and sent notification to Congress that it would not defend the provision if it were challenged in the courts. Furthermore, the OMB Director David Stockton sent out notice to all the heads of all the agencies instructing them to not act upon the invalid provision. When the administration informed the Congress that it would not recognize the constitutional validity of the provisioneven after a lower court ruled against it - the Congress responded by threatening to cut-off appropriations to the Department of Justice for FY 1986 and 1987. The administration quickly backed down. ${ }^{140}$

A motivated Congress can, in this way, leverage its power to cause the Executive Branch to concede or compromise some of its constitutional objections to laws.

Finally, "Congress may impeach and remove from office all who violate the Constitution, as Congress understands it." best reserved as a last resort, but it is not unprecedented. President Clinton was impeached for perjury and obstruction of justice, and President Andrew Johnson was impeached for violation of the Tenure of Office Act, which as previously discussed was later invalidated as unconstitutional. Neither was convicted and removed from office, but needless to say, impeachment is a palpable deterrent to presidential abuse of power.

It should be noted that it appears, historically, that these and other congressional checks on Executive power have generally served their purpose as it relates to presidential signing statements and Executive assertions of the authority to construe statutes. "Critics . . . are mistaken to equate presidential refusals to enforce constitutionally objectionable laws with a line-item veto or dispensing authority, on the reasoning that Presidents routinely will convert policy objections into constitutional

140. Id. at 14-15 (footnotes omitted). See supra notes 90-92 and accompanying text for more detail regarding the lower court's ruling on the legitimacy of the administration's position.

141. Easterbrook, supra note 99, at 912 (emphasis added). 
arguments." 142 On the contrary, "[t]wo centuries of experience establish that the President, too, is capable of principled constitutional interpretation. Presidents... have a long tradition of interpreting the Constitution ... and much of the constitutional analysis is memorialized in written legal opinions of Attorneys General or the Office of Legal Counsel." "In addition, an empirical study recently conducted by the Government Accountability Office found that the majority of a representative sample of the provisions of the 2006 appropriations acts to which President Bush attached a signing statement were enforced as written. ${ }^{144}$ Of the six that were identified as having not been enforced as written, three were provisions attempting to institute a legislative veto and one was enforced in 38 days rather than the 21 days as directed by the statute. ${ }^{145}$ Furthermore, the report stated that although some "agencies did not execute the provisions as enacted, we cannot conclude that agency noncompliance was the result of the President's signing statements." 146

The President has a special duty to the Oval Office and to the Constitution to avoid acquiescing in the erosion of Executive authority. When faced with a statute that impermissibly encroaches on Executive prerogatives, to which a veto is impracticable, the President should employ the avoidance canon in a signing statement, announcing intent to construe the statute in a manner that will give it the fullest possible effect without violating the Constitution. The President should pay special attention to the potential for judicial review, and endeavor to make that happen if at all possible. In the event that judicial review is not likely or possible, Congress possesses a number of tools with which to check the President from manipulating his power to advance his own ambitions rather than an equitable understanding of the constitutional separation of powers.

142. Johnsen, supra note 79 , at 41 . The dispensing authority is another name for the suspending power discussed at supra note 84 .

143. Id. at 40 .

144. U.S. Government Accountability Office Report, Presidential Signing Statements Accompanying the Fiscal Year 2006 Appropriations Acts, No. B-308603, June 18, 2007, at 1, 13-19, available at http://www.gao.gov/decisions/appro/308603.pdf [hereinafter GAO Report]. The Government Accountability Office is an independent, nonpartisan agency that helps Congress ensure the performance and accountability of the federal government.

145. Id. at 10

146. Id. at 9 . 


\section{B. Addressing Other Constitutional Concerns}

The President should follow a similar approach for constitutional concerns other than those grounded in separation of powers issues, such as individual rights or federalism. Again, if the constitutional defect is clearly established by Supreme Court precedent, the President should either veto the bill or issue a detailed signing statement to announce the intent to construe it to avoid the defect, thereby affording the Legislature the fullest constitutional effectuation of its wishes.

The enforcement of constitutionally defective statutes which do not implicate separation of powers concerns is much more likely to produce justiciable cases or controversies. ${ }^{147}$ In these situations, there will usually be an individual who is harmed by a deprivation of a constitutional or statutory right stemming from the Executive's enforcement choices. For example, if Congress passes an affirmative action statute, but the President chooses to enforce it so that it avoids perceived Equal Protection Clause violations, a would-be beneficiary of the law may have standing to sue for an injury resulting from the agency or entity failing to strictly comply with the statute as written. Because of the greater likelihood of judicial review, in addition to the congressional checks previously discussed, ${ }^{148}$ the risk of presidential abuse of the avoidance canon in these sorts of situations is minimal.

The rationale behind carefully issuing highly specific and detailed signing statements applies with equal force to constitutional challenges involving issues other than the separation of powers. Signing statements such as this exhibit the fundamental respect owed the Congress in the Article I enactment process by requiring the President to demonstrate the legitimate constitutional moorings for his position. At the same time, the President is able to exercise his own constitutional determinations regarding the laws which will affect the lives of Americans.

"Case or controversy requirements and restrictions against courts issuing advisory opinions do not, of course, apply to the executive's internal constitutional decisionmaking, and presidents can better serve individual rights to the extent that they expressly stake out their constitutional commitments in general and in advance of any concrete controversy." "149 Because of the lack of these familiar restrictions placed

147. See Easterbrook, supra note 99, at 927 (discussing the "live controversies" and "real cases" that initiate constitutional review).

148. See supra notes 134-41 and accompanying text (discussing the means by which Congress may influence Executive enforcement choices).

149. Cornelia T.L. Pillard, The Unfulfilled Promise of the Constitution in Executive Hands, 103 
on the courts, the Executive possesses a particular institutional strength: "the ability to reach out and tackle a problem, rather than wait for it to come knocking." 150 It is thus desirable for the President to proactively wrestle with constitutional questions regarding statutes he signs, and challenge them using a presidential signing statement and the avoidance canon if need be. In this way, the Executive can help prevent a constitutional violation from befalling a citizen without waiting for a definitive ruling from the Supreme Court.

But constitutional violations do inevitably befall citizens, who inevitably bring civil rights actions against government actors. Even here, the Supreme Court's qualified immunity jurisprudence should uniquely counsel Presidents to carefully craft precise signing statements when challenging the constitutionality of statutes which may impact individual rights. The Court has held that "government officials performing discretionary functions generally are shielded from liability for civil damages insofar as their conduct does not violate clearly established statutory or constitutional rights of which a reasonable person would have known." 151

When evaluating a claim of qualified immunity, a strict two-step rule of procedure applies such that "[a] court... "must first determine whether the plaintiff has alleged the deprivation of an actual constitutional right at all, and if so, proceed to determine whether that right was clearly established at the time of the alleged violation." "152 In other words, the court must determine the constitutionality of the statute in question before it can decide whether the government actor enjoys qualified immunity. Thus, when Executive employment of the avoidance canon results in civil rights litigation, it may have the ironic effect of forcing the court to abandon its own traditional adherence to the avoidance canon in order to confront and decide the constitutionality of the statute in question. The result would be more final judicial resolutions of constitutional questions, leading to more consistency and predictability in the law.

Additionally, a well-articulated signing statement expressing plausible doubt about the constitutionality of the statutory right at issue may very well impact a court's determination of whether the right was clearly established at the time of the violation. Even if the Executive's

\footnotetext{
MiCH. L. REV. 676, 745 (2005).

150. Id. at 755 .

151. Harlow v. Fitzgerald, 457 U.S. 800, 818 (1982) (emphasis added).

152. Wilson v. Layne, 526 U.S. 603, 609 (1999) (quoting Conn v. Gabbert, 526 U.S. 286, 290 (1999)).
} 
position as expressed in the signing statement is ultimately rejected by the court, a strong argument will remain that the official was reasonably endeavoring to execute the law in a manner consistent with the President's interpretation of it, and thus that the right was not clearly established at the time the official acted. The qualified immunity inquiry thus provides at least two incentives-more frequent final adjudication of constitutional questions and more expansive qualified immunity protection for officials - encouraging the President to apply the avoidance canon in a principled, reasonable, and restrained fashion. General assertions of Executive authority and baseless constitutional challenges are not likely to persuade a court that the official reasonably relied upon the President's signing statement in executing the statute at issue in the way that she did.

\section{Implications of Application}

\section{Remarkable Benefits}

The benefits of using presidential signing statements to employ the avoidance canon are many. First, the practice encourages transparency and accountability within the Executive Branch. "The more the public understands what is at stake in executive constitutionalism, the more pressure it can bring to bear on the executive to do it fully and well.",153 In other words, if the Executive Branch is going to continue to selectively enforce statutes based on constitutional concerns - as it has a long history of doing - then the practice should be exposed to as much light as possible. That exposure will require the Executive to express its concerns in a way that is defensible in the balance of powers between the branches as well as in the public eye. The measure of defensibility will be directly proportional to the precision and care with which the timehonored avoidance canon is applied in the vehicle of publicly scrutinized presidential signing statements.

Second, the practice is an appropriate, moderate defense against the erosion of Executive authority. The President should, whenever possible, seek judicial review of statutes which intrude on Executive domain (such as legislative veto provisions or provisions infringing on the President's removal power, Commander-in-Chief authority, etc.) by taking the action most likely to set up a justiciable case or controversy. When judicial review is not possible, the President has a justifiable

153. Pillard, supra note 149 , at 750. 
incentive to aggressively defend Executive prerogatives. Careful application of the avoidance canon allows the President to achieve this end while simultaneously allowing Congress the fullest constitutional execution of its Acts. It should be noted, however, that the Court has recently signaled a willingness to hear cases involving the most sensitive types of separation of powers disputes, assuming jurisdiction and standing are present under traditional Article III principles. ${ }^{154}$ Examples include some of the recent cases arising out of Guantánamo Bay, such as Hamdan v. Rumsfeld, ${ }^{155}$ which held "that the President lacked authority to convene a military commission to try a Yemeni national under procedures that did not comply with the Uniform Code of Military Justice," Branch argument that out of respect for separation of powers, ... federal courts should not review the facts concerning individual cases of U.S. citizens held as enemy combatants, but should review only the legality of the overall detention scheme." 158 In any event, regardless of justiciability, the Legislature is equipped with adequate tools to check any abuse or manipulation by the President. ${ }^{159}$

Third, careful and thorough application of the avoidance canon may actually lead to increased opportunity for judicial review in individual rights situations due to the Supreme Court's unique qualified immunity jurisprudence. If an Executive official asserts qualified immunity as a defense to a civil rights action, claiming that the law in question was not "clearly established" as evidenced by the plausible doubt expressed in a signing statement, the reviewing court will be forced to address the underlying constitutional concern, to the benefit of all.

\section{Dangers Are Mitigable}

Critics articulate a number of concerns regarding presidential signing statements and the Executive practice of enforcing constitutionally objectionable statutes based on a saving construction. Among them is the possibility that courts will favor the Executive interpretation over congressional intent derived from legislative history when deciding the

\footnotetext{
154. Cooney, supra note 53, at 666.

155. 548 U.S. 557 (2006).

156. Cooney, supra note 53, at 666 n. 44 .

157. 542 U.S. 507 (2004).

158. Cooney, supra note 53, at 666 n.44.

159. See supra notes 134-41 and accompanying text (discussing the means by which Congress may influence Executive enforcement choices).
} 
constitutionality of a statute. ${ }^{160}$ The argument generally avers that " $[\mathrm{t}] \mathrm{o}$ rely on the [signing] statements... would violate the Constitution's separation of powers doctrine by both giving the President the power to make law and by allowing the President to usurp the judiciary's role of interpreting statutory meaning."

One response to this perceived danger is that empirical evidence shows that signing statements are rarely cited in court opinions. ${ }^{162}$ An exhaustive search of all published federal cases from 1945 to May 2007 found that only 137 federal court opinions cited or referred to presidential signing statements. ${ }^{163}$ When cited or referred to, they appear to have had little impact on judicial decisionmaking. ${ }^{164}$ Of the 137 opinions, only five of those were Supreme Court opinions, and the signing statement was discussed only in the dissenting opinion of two of those five. ${ }^{165}$ Thus, empirical evidence strongly shows that courts have not been prone to cite presidential signing statements, let alone rely on them for interpretation of a statute. Furthermore, commentators have noted that the Supreme Court, due to changing membership, has generally been moving away from honoring legislative history for the past two decades. ${ }^{166}$

Although the argument is largely moot due to this empirical evidence, there remains a convincing rationale supporting the treatment of presidential signing statements as part of the legislative history of a statute. Justice Frankfurter wrote "[i]f the purpose of construction is the ascertainment of meaning, nothing that is logically relevant should be excluded." 167 The President in fact plays a significant constitutional role in the enactment of legislation, from recommending legislation ${ }^{168}$ to signing or vetoing the same. ${ }^{169}$ The Executive Branch typically is heavily involved in suggesting legislation and then carefully monitoring

160. See Marc N. Garber \& Kurt A. Wimmer, Presidential Signing Statements as Interpretations of Legislative Intent: An Executive Aggrandizement of Power, 24 HARV. J. ON LEGIS. 363, 363 (1987).

161. Id. at 363 .

162. GAO Report, supra note 144, at 11.

163. Id. at 37 .

164. Id.

165. Id.

166. Note, Context-Sensitive Deference to Presidential Signing Statements, 120 HARV. L. REV. 597, 604 (2006).

167. Felix Frankfurter, Some Reflections on the Reading of Statutes, 47 CoLuM. L. REV. 527, 541 (1947).

168. See U.S. ConST. art. II, $\S 3$ (providing that the President shall recommend to Congress "such Measures as he shall judge necessary and expedient").

169. U.S. CONST. art. I, \& 7, cl. 2. 
it as it makes its way through the legislative process, attempting to inject input all along the way. ${ }^{170}$ This state of affairs has led at least one political commentator to suggest that "the legislature is not the dominant influence in the legislative process. The President is more influential.",171 The Second Circuit acknowledged the value of presidential involvement in enacting legislation in United States v. Story, writing that "President Reagan's views are significant here because the Executive Branch participated in the negotiation of the compromise legislation."

Admittedly, Executive proposal and monitoring of legislation occurs at a much earlier stage of the legislative process than enactment. But, because a bill cannot become law without the President's signature (absent an overridden veto), it stands to reason that his understanding of the law at signing is significant. His involvement in the process means that he may be as familiar with the bill as anyone in Congress. And his understanding of the statute is also likely to be informed by real-world enforcement expertise. Both of these factors make the President's views of a bill at signing at least relevant to a Court's interpretation of constitutionality. The potential for manipulation is checked by Congress's previously mentioned tools, such as oversight, appropriations, and impeachment. ${ }^{173}$

A second perceived danger regarding the practice of signing statements and Executive construction of statutes is that the President will abandon the veto in favor of this new device, disrupting the separation of powers and the venerated system of checks and balances. ${ }^{174}$

Again, this concern can be quieted with empirical evidence. First, the GAO study that concluded that most of the 2006 appropriations provisions are being enforced as written notwithstanding the issuance of signing statements is illustrative of the fact that signing statements do not constitute some kind of mad Executive power grab. ${ }^{175}$ Second, as discussed previously, the signing statement has no intrinsically legally binding effect. ${ }^{176}$ If the President vehemently disfavored a piece of legislation, believing it to be poor policy, his better option would be the

\footnotetext{
170. Kathryn Marie Dessayer, Note, The First Word: The President's Place in "Legislative History," 89 Mich. L. REV. 399, 406-07 (1990).

171. Id. at 408 (quoting ARTHUR MAASS, CONGRESS AND THE COMMON GOOD 15 (1983)).

172. 891 F.2d 988, 994 (2d Cir. 1989).

173. Supra notes $134-41$ and accompanying text.

174. See ABA REPORT, supra note 44, at 1 (opposing the issuance of signing statements as contrary to "our constitutional system of separation of powers"); Savage, supra note 39 (reporting that signing statements skirt the constitutional system of checks and balances).

175. Supra note 144 and accompanying text.

176. Supra notes 53-58 and accompanying text.
} 
traditional veto which would keep it off the books not only during his presidency, but permanently. Furthermore, in no case should a President issue a signing statement outlining an intention to construe a statute to conform simply to his policy preferences. Such a situation would indeed violate the constitutional system of separation of powers.

The signing statement employing the avoidance canon indeed represents a new tool which may be used by Presidents to achieve their objectives. However, the acquisition of new devices such as this one is not unique to the George W. Bush presidency. Presidential scholar Ryan Barilleaux argues that pushing at the ambiguous and vague boundaries of Article II is what Presidents must do in order to keep up with their many urgent and evolving responsibilities. ${ }^{177} \mathrm{He}$ calls this behavior "Venture Constitutionalism," defined as "an assertion of constitutional legitimacy for presidential actions that do not conform to settled understandings of the President's constitutional authority."178 For example, Thomas Jefferson purchased the Louisiana Territory when there was no clear understanding of how the country might acquire new territory, Abraham Lincoln asserted unprecedented powers during an unprecedented Civil War, and "Jimmy Carter asserted the unilateral authority to terminate a treaty in force," an action later upheld in Goldwater v. Carter. ${ }^{179}$

The actions tend to fall into one of three categories: actions designed to protect the president's institutional interests such as Andrew Jackson's refusal to acknowledge the validity of the Tenure in Office Act; actions designed to promote national security and the advancement of our national interests, such as the actions Lincoln took during the Civil War; and finally actions designed to help the president shape policy.

"The only thing that limits a venturing president is the Congress, which has the institutional capacity and resources to take on the most aggressive of presidents. But it has to muster the will to do so." ${ }^{\prime 181}$ If the avoidance canon is carefully applied within presidential signing statements, there is little opportunity for abuse or manipulation because sufficient congressional checks are in place.

177. Ryan J. Barilleaux, Venture Constitutionalism and the Enlargement of the Presidency, in EXECUTING THE CONSTITUTION 37, 40 (Christopher S. Kelley ed., 2006).

178. Id. at 42 .

179. Id. at $44-46$

180. Kelley, supra note 134, at 20-21 (citing Barilleaux, supra note 177, at 44).

181. Id. at 21. 


\section{CONCLUSION}

Executive employment of the avoidance canon in presidential signing statements is a useful tool for the protection of legitimate Executive prerogatives. Additionally, when carefully applied, it may lead to more opportunity for judicial review of constitutional questions, leading to more consistent and predictable law. Out of appropriate deference to the Legislature, when the veto is wholly impractical, the President should construe statutes to avoid constitutional peril, thereby affording Congress the fullest constitutional enforcement of the law.

Presidents must also keep in mind that application of the avoidance canon to the Acts of Congress may not be the most politically expedient decision. President Bush is still suffering fallout from the signing statement attached to the McCain Amendment prohibiting the cruel, inhuman, or degrading treatment of detainees. President Bush's use of signing statements has even become an issue in the 2008 presidential campaign rhetoric. Senator John McCain has promised that he "would never issue a signing statement," "182 Senator Hillary Clinton conceded that she might "in very rare instances"” attach a signing statement to " "provisions that contradict the Constitution,", 183 and Senator Barack Obama has argued that "“[n]o one doubts that it is appropriate to use signing statements to protect a president's constitutional prerogatives; unfortunately, the Bush administration has gone much further than that." 184 These statements clearly support the notion that although the President may have a legitimate constitutional separation of powers concern with any given statute, preserving political goodwill with Congress may often be the more strategically sound move.

With sufficient congressional checks and safeguards in place, Presidents may successfully and accountably borrow the judiciary's avoidance canon to construe the Acts of Congress in a manner that comports with the Executive interpretation of the Constitution. Congress is equipped with powerful tools, such as oversight, appropriations, and impeachment, with which to encourage the Executive to remain faithful to congressional intent when judicial review of Executive enforcement or non-enforcement is not possible. And when Executive interpretation and enforcement choices impact American citizens and lead to civil rights

182. Charlie Savage \& James W. Pindell, A Tactic of Bush's on Bills is Assailed, Boston GLOBE, Nov. 20, 2007, at 14A.

183. Charlie Savage, Candidates on Executive Power: A Full Spectrum, Boston Globe, Dec. 22,2007 , at $1 \mathrm{~A}$.

184. Id. 
litigation, the peculiarities of qualified immunity jurisprudence will require final judicial resolution of the constitutional disagreement between Congress and the President. In this way, Executive application of the avoidance canon in presidential signing statements is a reasonable and observable method by which Presidents may best fulfill their obligations to execute the law and uphold the Constitution, while simultaneously allowing Congress the greatest effectuation of its Acts as constitutionally permissible. 